\title{
MELIMEX, an experimental heavy metal pollution study: Chemical speciation and biological availability of copper in lake water
}

\author{
By Peter Baccini and Ursula Suter \\ Swiss Federal Institute for Water Resources and Water Pollution Control (EAWAG) at Swiss Federal \\ Institutes of Technology (ETH)
}

Manuscript received on 28 June 1979

\begin{abstract}
The chemical speciation of dissolved copper was investigated in waters from the limno-corrals of the MELIMEX project and compared with speciation data from other Swiss lakes. Copper is complexed primarily by organic ligands having molecular sizes between $10^{4}$ and $10^{3}$ daltons. The mean concentration of the ligands is approximately $5 \times 10^{-7} \mathrm{~mole} / \mathrm{mg}$ DOC. The conditional stability constants $(\mathrm{pH}=8.8)$ are about $10^{11}$. An increased metal load did not induce an increase of binding ligands. A comparison of calculated $\mathrm{Cu}^{2+}$ concentration with corresponding copper contents in the biomass leads to the conclusion that organic ligands and $\mathrm{pH}$ are the most important factors in deciding the biological availability of copper. However the sorption capacity of the biomass depends as well on the variety of plankton species.
\end{abstract}

\section{Introduction}

The study of metal balances in natural lakes and limno-corrals has shown that the biota of a limnic system are not able to reduce drastically the concentration of heavy metals such as $\mathrm{Cu}, \mathrm{Zn}, \mathrm{Cd}, \mathrm{Hg}$ and $\mathrm{Pb}$ by assimilation and sedimentation $[1,2]$. Investigations of the effects of increased heavy metal concentration on algae photosynthesis and plankton variety indicate furthermore that no buffer system exists, or is produced that would efficiently control the biologically available forms of these elements [3]. In other words an increased metal concentration in the aquatic phase leads to a higher concentration in the biophase.

However more detailed analysis of the influence of unknown natural and welldefined synthetic ligands on the biological availability of heavy metal species for primary producers lead to the conclusion that especially in the case of copper there exist ligands which can form thermodynamically stable complexes even in concentration ranges below $10^{-7} \mathrm{M}$ [4-7].

Limnological experience tells us that the biosphere of a lake is the only active element within the system which can influence the chemical composition of the aquatic environment, be it by fluxes of protons or electrons or be it by producing 
dissolved organic molecules and adsorbing surfaces with certain ligand properties. While inorganic metal speciation is predictable to a reasonable degree of accuracy, the role of organic molecules in complexing with metals is very poorly known because of a lack of sufficient information on the structure, concentration or complexing ability of the natural organic ligands.

Theoretical investigations of artificial aquatic systems, based on speciation calculation for multi-metal/multi-ligand equilibria, supported experimental evidences $[8,9]$ that among the heavy metals copper would most likely be complexed by organic ligands. From a thermodynamic point of view however, simple monomeric ligands such as amino acids, citric acids or salicyclic acids cannot form stable copper complexes in competition with inorganic ligands in hard waters under natural conditions.

The MELIMEX project was therefore chosen to answer the following question:

Can an aquatic system react to an increased heavy metal load by varying

a) the concentration and

b) the chemical nature of ligands so that the thermodynamic stability of the corresponding metal complexes is changed in such a way that the biological availability of the metal is regulated?

The theoretical considerations and the experimental facts mentioned above asked for a methodology that is suited primarily to study copper.

\section{Methods}

\subsection{Experimental design of the MELIMEX project}

Three limno-corrals of $12 \mathrm{~m}$ in diameter and of a mean depth of $10 \mathrm{~m}$ were installed at the northern end of Lake Baldegg. A system of pumps was used to pump water into and out of the limno-corrals. One corral served as control (C). Its metal concentrations were identical to ambient concentrations of the lake. Two corrals (L1, L2) had the following average inflow concentrations of metals $\left(10^{-8} \mathrm{M}\right)$ :

- Copper: 18,

- zinc: 320 ,

- cadmium: 4.5,

- mercury: 0.5 ,

- lead: 24.

These values correspond to the maximum concentrations legally tolerated in Swiss running waters.

Detailed informations about the experimental design of the MELIMEX project are given by Gächter [25].

\subsection{Main principles considered in the choice of methods}

The analytical techniques presently available cannot provide detailed information on metal speciation in a lake water for concentration ranges below $10^{-7} \mathrm{M}$. It is therefore necessary to choose a concentration step. Any introduction of new reagents 
or any variation of the ionic strength may change the original nature of the trace components in question. The demand for no chemical perturbation can hardly be fulfilled. It was decided to compare the thermodynamic properties of different ligands in the dissolved fraction of the lake water samples, i.e. the activity of complexing agents and the formation constants of the corresponding metal complexes. To simplify the approach it was assumed that there exists at least one type of organic ligand which can compete with the known inorganic ligands present in a freshwater system, namely $\mathrm{OH}^{-}$and $\mathrm{CO}_{3}^{2-}$. The dissolved organic carbon content gives an upper limit for the possible concentration of an organic ligand. If one assumes an average molecular weight of 2,000 [10] for a copper binding site, having a carbon content of $50 \%$, a lake water with a DOC concentration of $1 \mathrm{mg} / \mathrm{l}$ would offer approximately $1 \times 10^{-6} \mathrm{M}$ copper binding ligands. Therefore the analytical methods applied must primarily detect ligands which have conditional formation constants which are equal to or greater than $10^{9}$ (fig. 1). All other ligands cannot compete significantly with the inorganic forms.

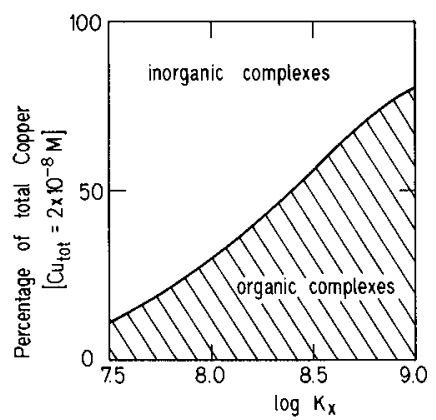

Figure 1. Predicted copper distribution between inorganic and organic complexes as a function of the stability constant $\mathbf{K}_{\mathbf{X}}$.

Chosen inorganic species (24) and corresponding complex formation constants (log values in parenthesis): $\mathrm{Cu}^{2+}, \mathrm{CuOH}^{+}(6.0), \mathrm{Cu}(\mathrm{OH})_{2}(14.3), \mathrm{CuCO}_{3}(6.8), \mathrm{Cu}\left(\mathrm{CO}_{3}\right)_{2}^{2-}(10.4)$.

Ligand concentration: $\mathrm{pOH}=6.0,\left[\mathrm{CO}_{3}^{2-}\right]=2 \times 10^{-3} \mathrm{M}, \mathrm{X}_{\mathrm{tot}}=10^{-6} \mathrm{M}\left(\mathrm{K}_{\mathrm{X}}=\left[\mathrm{CuX}^{-}\left[\mathrm{Cu}^{2+}\right]^{-1}[\mathrm{X}]^{-1}\right)\right.$. Abb. 1. Berechnete Kupferverteilung zwischen anorganischen und organischen Komplexen als. Funktion der Stabilitätskonstanten $\mathrm{K}_{\mathbf{X}}$.

Gewählte anorganische Spezien (24) und entsprechende Komplexbildungskonstanten (logarithmische Werte in Klammern).

In order to obtain clues from thermodynamic data about the possible functional groups involved one has to know the order of magnitude of the molecular sizes. It is well known that macromolecular polyelectrolytes or colloidal forms would lead to thermodynamic data which describe only the bulk property of the operationally defined dissolved phase. On the contrary ligands with molecular sizes smaller than $10^{4}$ daltons could be considered as copper binding molecules which are dissolved in the physicochemical sense.

To obtain information on copper speciation we used the scheme outlined in figure 2. Initially the lake water sample $(<0.45 \mu \mathrm{m})$ was concentrated within the 
Scheme of method combination in copper speciation analysis

( $C F=$ Concentration factor)

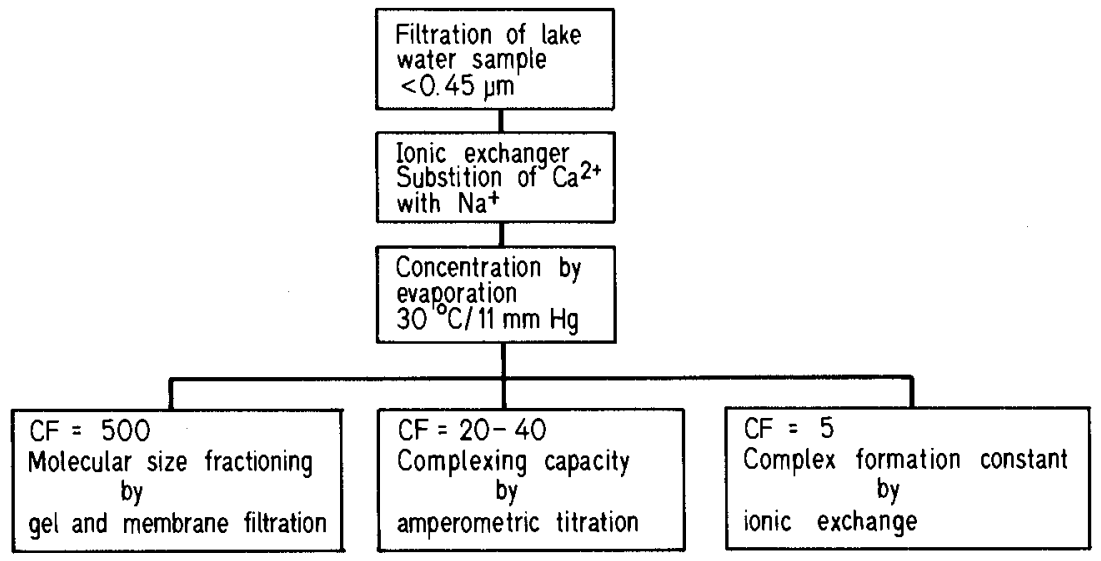

Figure 2. Scheme of method combination in copper speciation analysis $(\mathrm{CF}=$ concentration factor $)$. Abb.2. Schema der Methodenkombination in der Kupferspeziierungsanalyse ( $\mathrm{CF}=$ Konzentrierungsfaktor).

observed natural $\mathrm{pH}$ region between 8 and $9 . \mathrm{Ca}^{2+}$ was substituted with $\mathrm{Na}^{+}$to prevent coprecipitation of organic molecules with $\mathrm{CaCO}_{3}$.

1. The concentrated solution was then treated in three ways: The equivalent concentration of copper binding ligands was determined using an amperometric titration at a $\mathrm{pH}$ between 8 and 9 . As resumed by Hanck [11] this property is called 'complexing capacity' by most authors.

2. A conditional complex formation constant was determined in observed natural $\mathrm{pH}$ region between 7.5 and 9 using the technique of copper distribution between an ionic exchanger and an aquatic phase.

3. The organic ligands were fractionated into molecular sizes by employing gel and membrane filtration techniques.

\subsection{Sample collection}

Samples for the speciation analysis were taken monthly from the MELIMEX corrals in Niskin bottles from March 1977 until April 1978. Equal volumes from depths of $0,1,2$ and $3 \mathrm{~m}$ from each loaded corral were mixed in a 201 polyethylene bottle. In an analogous procedure samples were taken from the control corral and, for comparison, from other lakes.

The mixtures were filtrated within 3 hours after the sampling through a $0.45 \mu \mathrm{m}$ filter (Millipore). 


\subsection{Concentration procedure}

101 of the sample were eluted through a column (length $35 \mathrm{~cm}$, diameter $5 \mathrm{~cm}$ ) packed with $120 \mathrm{~g}$ of a cation exchanger (Whatman CM 32) which was cleaned according to the manufacturer's instruction and converted to the $\mathrm{Na}^{+}$-form by washing with $2 \times 10^{-3} \mathrm{M} \mathrm{NaHCO}_{3}\left(\mathrm{pH}=8.1 \pm 0.1\right.$ flow rate $\left.4 \mathrm{ml} \mathrm{min}^{-1}\right)$. The retention of heavy metals and the dissolved organic carbon on the column is given in Table 1. Dissolved organic substances and copper in natural concentrations are hardly retained. 101 of the eluate were concentrated by rotary evaporation in a Rotavap R (Büchi) at $30^{\circ} \mathrm{C} / 15 \mathrm{~mm} \mathrm{Hg}$ to a volume of $100 \mathrm{ml}$ (concentrating factor $\mathrm{CF}=100$ ). The yellow liquid had a $\mathrm{NaHCO}_{3}$ concentration of approximately $0.3 \mathrm{M}$ and a $\mathrm{pH}=9 \pm 0.1$. It was stored at $4{ }^{\circ} \mathrm{C}$.

Table 1. Retention ability $\mathbf{R}$ of the cation exchanger column.

$\mathbf{R}=\frac{\text { Eluate concentration } \times 100}{\text { Input concentration }}$.

Tabelle 1. Rückhaltekapazität $\mathbf{R}$ der Kationenaustauscher-Kolonne.

$\mathbf{R}=\frac{\text { Eluatkonzentration } \times 100}{\text { Inputkonzentration }}$.

\begin{tabular}{lllllll}
\hline $\begin{array}{l}\text { Parameter } \\
\text { Medium }\end{array}$ & $\begin{array}{l}\mathrm{DOC} \\
(\mathrm{n}=10)\end{array}$ & $\begin{array}{l}\mathrm{Cu} \\
(\mathrm{n}=10)\end{array}$ & $\begin{array}{l}\mathrm{Zn} \\
(\mathrm{n}=3)\end{array}$ & $\begin{array}{l}\mathrm{Cd} \\
(\mathrm{n}=3)\end{array}$ & $\begin{array}{l}\mathrm{Pb} \\
(\mathrm{n}=3)\end{array}$ & $\begin{array}{l}\mathrm{Fe} \\
(\mathrm{n}=3)\end{array}$ \\
\hline Lake water & $93 \pm 7$ & $74 \pm 25$ & $11 \pm 10$ & $40 \pm 15$ & $8 \pm 4$ & 0 \\
$\mathrm{Ca}\left(\mathrm{HCO}_{3}\right)\left(\mathrm{Cl}^{-}\right)^{* *}$ & - & $9 \pm 4$ & $9 \pm 4$ & $14 \pm 4$ & $9 \pm 4$ & - \\
\hline
\end{tabular}

* The metal concentration varied within the values observed in the dissolved fractions of the control container (2). The dissolved iron concentration amounted to $4-8 \times 10^{-8} \mathrm{M}$.

** The calcium concentration was equal to the average $\mathrm{Ca}$ concentration found in lake water samples of the MELIMEX containers $\left(1.5 \times 10^{-3} \mathrm{M}\right)$.

$\mathrm{n}=$ number of experiments.

\subsection{Amperometric titration of copper binding ligands}

\subsection{Analytical technique}

The location of the equivalence point at trace levels by a polarographic method is based on earlier observations $[12,13]$, namely that sea and lake water samples can bring $\mathrm{Cu}$ into an electrochemically inactive form. By choosing a medium of $0.1 \mathrm{M} \mathrm{NaHCO}$ at a $\mathrm{pH}=8.8$ the electroactive copper species are $\mathrm{CuCO}_{3}$ and $\mathrm{Cu}\left(\mathrm{CO}_{3}\right)_{2}$. In such a medium, if ligand concentrations of approximately $10^{-4} \mathrm{M}$ $(\mathrm{CF}=50$ relative to lake water) are to be determined with an accuracy of $\pm 30 \%$, the complex formation constant must be greater than $10^{10}$. This is shown in figure 3 . In figure 4 the method is illustrated assuming NTA as the ligand.

\subsection{Analytical procedure}

$4 \mathrm{ml}$ of concentrated lake water samples $(\mathrm{CF}=100)$ were diluted with $0.1 \mathrm{M}$ $\mathrm{NaHCO}_{3}$ to $20 \mathrm{ml}$ and adjusted with $0.1 \mathrm{M} \mathrm{NaOH}$ to $\mathrm{pH}=8.8$. The sample was 


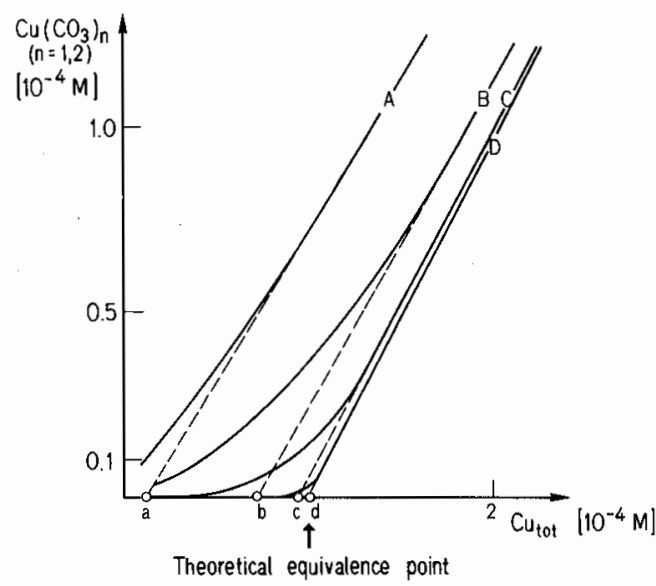

Figure 3. Amperometric titration: Theoretical titration curves for a ligand $\mathrm{X}$ in $0.1 \mathrm{M} \mathrm{NaHCO}$ at $\mathrm{pH}=8.8$.

Abb.3. Amperometrische Titration: Theoretische Titrationskurven für einen Liganden $\mathrm{X}$ in $0,1 \mathrm{M}$ $\mathrm{NaHCO}_{3}$ bei $\mathrm{pH}=8,8$.

\begin{tabular}{llll}
\hline $\begin{array}{l}\text { The equivalence point determination } \\
\log \mathrm{K}_{\mathbf{X}}\end{array}$ & Curve & $\left.\mathrm{X}_{\mathrm{tot}}=1 \times 10^{-4} \mathrm{M}\right)$ as a function of $\mathrm{K}_{\mathbf{X}}$ & \\
\hline 9.0 & A & Equivalence point & Relative error $(\%)$ \\
10.0 & B & a & -90 \\
11.0 & C & b & -28 \\
12.2 & D & c & -6 \\
\hline
\end{tabular}

* Intersection of the extended straight line of the linear part of the curve with the abscissa.

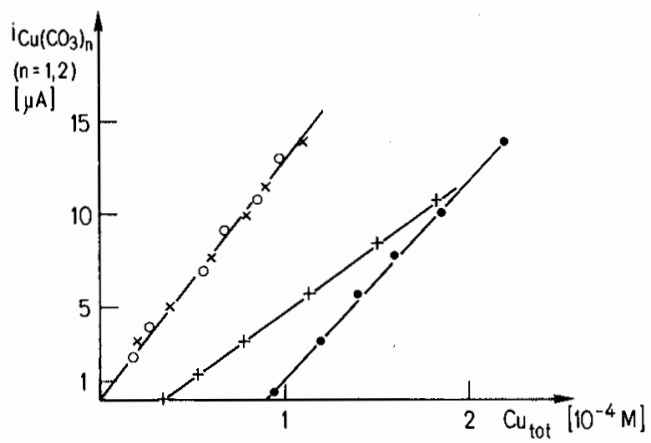

Figure 4. Amperometric titration of NTA and organic ligands X from lake water samples in $0.1 \mathrm{M}$ $\mathrm{NaHCO}_{3}$ at $\mathrm{pH}=8.8$.

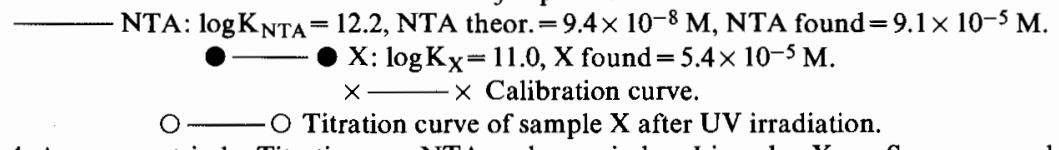

Abb.4. Amperometrische Titration von NTA und organischen Liganden $X$ aus Seewasserproben in $0,1 \mathrm{M} \mathrm{NaHCO}$ bei $\mathrm{pH}=8,8$. 
titrated in 5-100 $\mu \mathrm{l}$ steps with a $10^{-2} \mathrm{M} \mathrm{Cu}\left(\mathrm{NO}_{3}\right)_{2}$ solution using a Mettler DV 201 burette. The electrochemical cell was equipped with a standard dropping mercury electrode (DME), a platinum electrode and a calomel reference electrode. The cell was connected to a PAR Model 174 Polarographic Analyzer (Princeton Applied Research Corp.) in combination with a Omnigraphic 2000 Recorder (Houston Instrument Corp.). The differential pulse operation mode was applied. The half wave potential for the $\mathrm{Cu}\left(\mathrm{CO}_{3}\right)^{0}$ species had a value of $-0.11 \pm 0.01 \mathrm{~V}$. Below the equivalence point lake water samples showed broad and small peaks between $\mathrm{E}=-0.2$ and $-0.1 \mathrm{~V}$ which changed little while adding $\mathrm{Cu}(\mathrm{II})$. However lake water samples decreased the sensitivity $(\mu \mathrm{A} / \mathrm{mole})$ of the method (fig.4).

This is probably due to the reduction of the electroactive surface of the mercury drop caused by coating macromolecules [26]. After a treatment of a lake water sample with UV irradiation and $100 \mu \mathrm{H}_{2} \mathrm{O}_{2}(30 \%)$ during 2 hours the titration curve was identical with the calibration curve.

\subsection{Determination of the conditional complex formation constant}

\subsection{Principles}

In a two-phase system consisting of a cation exchange resin (suspended solid phase) and an aqueous $\mathrm{NaHCO}_{3}$ solution the soluble copper fraction which can be measured is expressed as a function of the thermodynamic properties of the ligands in solution. A system having only inorganic ligands in solution can be described as follows:

$$
\left[\mathrm{Cu}_{\text {tot }}\right]=[\mathrm{CuI}]+[\mathrm{CuR}]+\left[\mathrm{Cu}^{2+}\right]
$$

where $[\mathrm{CuI}]$ is the sum of all inorganic complexes in aqueous solution, and $[\mathrm{CuR}]$ is the concentration of the copper complexes by the resin.

$$
\begin{aligned}
& \mathrm{K}_{\mathrm{I}}=\frac{[\mathrm{CuI}]}{\left[\mathrm{Cu}^{2+}\right][\mathrm{I}]}, \\
& \mathrm{K}_{\mathrm{R}}=\frac{[\mathrm{CuR}]}{\left[\mathrm{Cu}^{2+}\right][\mathrm{R}]} .
\end{aligned}
$$

The soluble copper fraction $\lambda_{0}$ is defined as

$$
\lambda_{0}=\frac{[\mathrm{CuI}]+\left[\mathrm{Cu}^{2+}\right]}{\left[\mathrm{Cu}_{\mathrm{tot}}\right]} .
$$

If $\left[R_{\text {tot }}\right]$ and $\left[I_{\text {tot }}\right]$ are $\gg \mathrm{Cu}_{\text {tot }}$ and $K_{I}$ and $K_{R}$ are $\gg 1 . K_{R}$ can be determined at a certain $\mathrm{pH}$ according to

$$
\mathrm{K}_{\mathrm{R}}=\mathrm{K}_{\mathrm{I}} \frac{\left[\mathrm{I}_{\mathrm{tot}}\right]}{\left[\mathrm{R}_{\mathrm{tot}}\right]} \frac{\left(1-\lambda_{0}\right)}{\lambda_{0}}
$$


The introduction of a soluble organic ligand $\mathrm{X}$ forming a complex $\mathrm{CuX}$ influences the copper distribution as follows:

$$
\begin{aligned}
& {\left[\mathrm{Cu}_{\mathrm{tot}}\right]=[\mathrm{CuI}]+[\mathrm{Cu} \mathrm{R}]+[\mathrm{Cu} \mathrm{X}]+\left[\mathrm{Cu}^{2+}\right],} \\
& \mathrm{K}_{\mathrm{X}}=\frac{[\mathrm{CuX}]}{[\mathrm{Cu}][\mathrm{X}]} .
\end{aligned}
$$

The soluble copper fraction $\lambda_{\mathrm{X}}$ is defined as follows

$$
\lambda_{\mathrm{X}}=\frac{[\mathrm{CuI}]+[\mathrm{CuX}]+\left[\mathrm{Cu}^{2+}\right]}{\left[\mathrm{Cu}_{\mathrm{tot}}\right]} .
$$

If $\left[\mathrm{X}_{\mathrm{tot}}\right] \gg\left[\mathrm{Cu}_{\mathrm{tot}}\right]$ and $\mathrm{K}_{\mathrm{X}} \gg 1$ then

$$
\mathrm{K}_{\mathrm{X}}=\frac{\mathrm{K}_{\mathrm{I}}\left(\lambda_{\mathrm{X}}-\lambda_{0}\right)}{\left[\mathrm{X}_{\mathrm{tot}}\right]\left(1-\lambda_{\mathrm{X}}\right) \lambda_{0}}
$$

With an organic ligand $\mathrm{X}=\mathrm{A}$ whose complex formation constant is $\mathrm{K}_{\mathrm{A}}$ and concentration $\left[A_{\text {tot }}\right]$ is known $K_{I}$ can be determined:

$$
\mathrm{K}_{\mathrm{I}}=\frac{\mathrm{K}_{\mathrm{A}}\left[\mathrm{A}_{\mathrm{tot}}\right]\left(1-\lambda_{\mathrm{A}}\right) \lambda_{0}}{\left(\lambda_{\mathrm{A}}-\lambda_{0}\right)}
$$

where $\lambda_{\mathrm{A}}$ is the corresponding soluble copper fraction. It follows that $\mathrm{K}_{\mathrm{X}}$ can be determined as follows:

$$
\mathrm{K}_{\mathrm{X}}=\frac{\mathrm{K}_{\mathrm{A}}\left[\mathrm{A}_{\mathrm{tot}}\right]\left(1-\lambda_{\mathrm{A}}\right)\left(\lambda_{\mathrm{X}}-\lambda_{0}\right)}{\left[\mathrm{X}_{\mathrm{tot}}\right]\left(1-\lambda_{\mathrm{X}}\right)\left(\lambda_{\mathrm{A}}-\lambda_{0}\right)} .
$$

$\lambda_{0}, \lambda_{\mathrm{A}}, \lambda_{\mathrm{X}}$ and $\left[\mathrm{X}_{\text {tot }}\right]$ are measurable quantities, $\mathrm{K}_{\mathrm{A}}$ and $\mathrm{A}_{\mathrm{tot}}$ are known values.

This equation is only valuable within the following range:

$$
1>\lambda_{\mathrm{X}} \approx \lambda_{\mathrm{A}}>\lambda_{0}>0 .
$$

Furthermore the analytical accuracy for a $\mathrm{Cu}$ distribution analysis at a concentration range of $10^{-7} \mathrm{M}$ demands the following maximum and minimum values for the distribution quotients:

$$
\begin{aligned}
& 0.9 \geq \lambda_{\mathrm{X}}, \lambda_{\mathrm{A}}>0.3, \\
& 0.3>\lambda_{0}>0.1 .
\end{aligned}
$$

It follows from (11) that for $\left(X_{t o t}\right) \approx\left(A_{t o t}\right) \approx 10^{-6} M$ the practical range for a $K_{X}$ determination of this method lies within three orders of magnitude, namely

$$
3 \times 10^{-2} \mathrm{~K}_{\mathrm{A}} \leq \mathrm{K}_{\mathrm{X}} \leq 3 \times 10^{\mathrm{I}} \mathrm{K}_{\mathrm{A}} .
$$


Organic ligands which can compete with inorganic ligands in lake water conditions and whose concentrations can be determined by the above mentioned amperometric titration method should have a conditional complex formation constant of at least $10^{10}(\mathrm{pH}=9.8)$. Therefore a value of $10^{12}$ for $\mathbf{K}_{\mathrm{A}}$ would be suitable. NTA whose $\mathrm{K}_{\mathrm{A}}(\mathrm{pH}=8.8)$ is $10^{12.2}$ was therefore chosen as reference ligand.

\subsection{Analytical procedure}

In $12 \mathrm{ml}$ test tubes with glass stoppers 4 batch series with 7 tubes containing $10 \mathrm{ml} 0.1 \mathrm{M} \mathrm{NaHCO}_{3}(\mathrm{pH}=8.8)$ and $\mathrm{Cu}(\mathrm{II})$-spikes from 1 to $6 \times 10^{-7} \mathrm{M}$ were prepared as follows:

1. Calibration series $\mathrm{C}$.

2. Inorganic series I: $+0.15 \mathrm{~g}$ ionic exchanger.

3. Reference series A: $+0.15 \mathrm{~g}$ ionic exchanger $+2 \times 10^{-6} \mathrm{M}$ NTA.

4. Ligand series $\mathrm{X}:+0.15 \mathrm{~g}$ ionic exchanger $+10^{-5} \mathrm{MX}(\mathrm{CF}=5)$.

The ionic exchanger (DOWEX $50 \mathrm{~W} \times 8,100-200 \mathrm{mesh}$ ) was first washed in $0.1 \mathrm{M} \mathrm{NaHCO}_{3}$.

The samples were shaken for 6 hours at $25^{\circ} \mathrm{C}$. After sedimentation of the resin the copper concentration of the supernatant solution was measured by atomic absorption spectroscopy (Perkin Elmer AAS 400 with graphite furnace HGA 74).

The quotients $\lambda_{i}(i=0, A, X)$ of equation (11) were calculated from the slopes $S_{i}$ of the corresponding straight lines (fig. 5):

$$
\lambda_{0}=\frac{\mathrm{S}_{0}}{\mathrm{~S}_{\mathrm{C}}}, \quad \lambda_{\mathrm{A}}=\frac{\mathrm{S}_{\mathrm{A}}}{\mathrm{S}_{\mathrm{C}}}, \quad \lambda_{\mathrm{X}}=\frac{\mathrm{S}_{\mathrm{X}}}{\mathrm{S}_{\mathrm{C}}} .
$$

Based on the relative errors of $S_{i}$ (e.g. $S_{C}= \pm 3 \%, S_{0}=12 \%, S_{A}= \pm 4 \%, S_{X}= \pm 6 \%$ ) the precision of the determination of $\mathrm{K}_{\mathrm{X}}$ was calculated according to

$$
\delta \mathrm{K}_{\mathrm{X}}=\left(\left[\left(\frac{\delta \mathrm{K}}{\delta \mathrm{X}}\right) \delta \mathrm{X}\right]^{2}+\sum\left[\left(\frac{\delta \mathrm{K}}{\delta \lambda_{\mathrm{i}}}\right) \delta \lambda_{\mathrm{i}}\right]^{2}\right)^{1 / 2}
$$

Giving for equation (11) the following relative error for $\mathrm{K}_{\mathrm{X}}$

$$
\begin{aligned}
\Delta \mathrm{K}_{\mathrm{X}}=\left[\left(\Delta \mathrm{X}_{\mathrm{tot}}\right)^{2}\right. & +\frac{\left(\lambda_{0}-2 \lambda_{\mathrm{X}}+1\right)^{2}}{\left(1-\lambda_{\mathrm{X}}\right)^{2}\left(\lambda_{\mathrm{X}}-\lambda_{0}\right)^{2}} \lambda_{\mathrm{X}}^{2}\left(\Delta \lambda_{\mathrm{X}}\right)^{2} \\
& +\frac{\left(\lambda_{0}-1\right)^{2}}{\left(1-\lambda_{\mathrm{A}}\right)^{2}\left(\lambda_{\mathrm{A}}-\lambda_{0}\right)^{2}} \lambda_{\mathrm{A}}^{2}\left(\Delta \lambda_{\mathrm{A}}\right)^{2} \\
& \left.+\frac{\left(\lambda_{\mathrm{X}}-\lambda_{\mathrm{A}}\right)^{2}}{\left(\lambda_{\mathrm{A}}-\lambda_{0}\right)^{2}\left(\lambda_{\mathrm{X}}-\lambda_{0}\right)^{2}} \lambda_{0}^{2}\left(\Delta \lambda_{0}\right)^{2}\right]^{1 / 2} .
\end{aligned}
$$

Applied for the example in figure $5 \Delta \mathrm{K}_{\mathrm{X}}$ amounts to $\pm 11 \%$. 


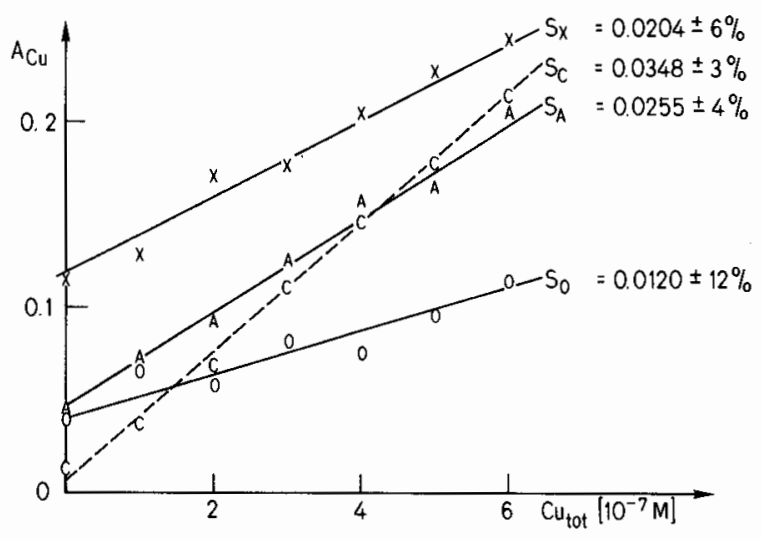

Figure 5. Batch procedure for the determination of the conditional complex formation constant $\mathrm{K}_{\mathrm{X}}$.

$A_{\mathrm{Cu}}$ : Absorbance of soluble copper fraction in AAS analysis at $325 \mathrm{~nm}$.

$\mathrm{S}_{\mathrm{X}}, \mathrm{S}_{\mathrm{A}}$ : Slopes for ligand $\mathrm{X}$ and reference ligand $\mathrm{A}$.

$\mathrm{S}_{\mathrm{C}}$ : Slope of calibration curve.

$\mathrm{S}_{0}$ : Slope of inorganic solution.

Abb.5. «Batch»-Verfahren für die Bestimmung der konditionellen Komplexbildungskonstanten $\mathbf{K}_{X}$.

$A_{C u}$ : Absorption der löslichen Kupferfraktion in der AAS-Analyse bei $325 \mathrm{~nm}$.

$\mathrm{S}_{\mathrm{X}}, \mathrm{S}_{\mathrm{A}}$ : Steigungen für den Liganden $\mathrm{X}$ und den Referenzliganden $\mathrm{A}$.

$\mathrm{S}_{\mathrm{C}}$ : Steigung der Eichgeraden.

$S_{0}$ : Steigung der anorganischen Lösung.

\subsection{Molecular size fractioning}

Because of the lack of sufficient knowledge about the chemical nature of copper binding ligands no effort was made to calibrate the separation techniques applied. Instead three different types of separations methods were used in order to assign one or several orders of magnitude for the molecular size of the ligands in question. This is illustrated in table 2 .

Table 2. Approximate spans of fractioning methods chosen.

Tabelle 2. Approximative Bereiche der gewählten Fraktionierungsmethoden.

\begin{tabular}{lcccc}
\hline MW (daltons) & $10^{5}$ & $10^{4}$ & $10^{3}$ & $10^{2}$ \\
Method & & $\mathrm{I}$ & $\mathrm{I}$ & $\mathrm{I}$ \\
\hline Gel-150 & & $\mathrm{I}$ & $\mathrm{I}$ \\
Gel-25 fine & & $\mathrm{I}$ & \\
Molecular filtration & & Ultrafiltration &
\end{tabular}

\subsection{Gel filtrations}

In order to detect possible variations of $\mathrm{Cu}$ distribution within a broad region of molecular size a gel with a large separation range was chosen (Sephadex G-150) to characterize the MELIMEX samples. For 5 hours $50 \mathrm{~g}$ of dry G-150 were 
swollen in $150 \mathrm{ml} 10^{-2} \mathrm{M} \mathrm{NaHCO}(\mathrm{pH}=8.1)$ at $90^{\circ} \mathrm{C}$. The packed column had a diameter of $2.5 \mathrm{~cm}$ and a length of $25 \mathrm{~cm} .1 \mathrm{ml}$ of concentrated lake water $(\mathrm{CF}=500)$ with the corresponding $\mathrm{Cu}$ concentration was eluted with $10^{-2} \mathrm{M}$ $\mathrm{NaHCO}_{3}(\mathrm{pH}=8.1 \pm 0.1) .25-30$ fractions of $10 \mathrm{ml}$ were isolated and analyzed for copper (AAS, see 2.62) and UV-light absorbing substances at $254 \mathrm{~nm}$ (Spectronic $200 \mathrm{UV}$, Bausch and Lomb). The volume $\mathrm{V}_{0}$ of the column was determined with Blue Dextran.

Separations with Sephadex G-25 fine were performed in an analogous procedure, starting from $25 \mathrm{~g}$ in $350 \mathrm{ml} 10^{-2} \mathrm{M} \mathrm{NaHCO}_{3}$.

\subsection{Membrane filtrations}

Two systems were applied. The Millipore Pellicon Cassette System with the membranes PSAC 00005 ( $10^{3}$ daltons as nominal molecular weight limit) was first washed with 4001 distilled water, followed by 11 of filtrated lake water, until no detectable DOC contamination was observed. 5.01 were then cycled in the system within 3 hours to give 0.11 retenate (MR) and 4.91 filtrate (MF). The filtrate MF was then concentrated according to section 2.4. From AMICON the ultrafiltration system type TCF 10 with the filter UM $2\left(10^{3}\right.$ daltons as nominal weight limit) was employed. 2.51 filtrated lake water $(<0.45 \mu \mathrm{m})$ was run through the system within 4 days at $4{ }^{\circ} \mathrm{C}$. The retentate volume was $0.077 \mathrm{l}(\mathrm{CF}=32.5)$.

\subsection{Complementary parameters}

\subsection{Dissolved organic carbon}

The DOC of the lake water samples were determined with an UNOR apparatus (detection limit): $0.2 \mathrm{mg} \mathrm{DOC} / \mathrm{l}$, precision: $\pm 0.1 \mathrm{mg} \mathrm{DOC} / \mathrm{l}$ ). The analysis of samples from molecular size fractioning were performed on Dohrmann DC-54 ultra low TOC analyzer (detection limit: $0.1 \mathrm{mg}$ DOC/l, precision: $\pm 0.05 \mathrm{mg}$ $\mathrm{DOC} / 1)$.

\section{$2.82 \mathrm{pH}$}

The $\mathrm{pH}$ of lake water samples was determined with a combined glass electrode.

\section{Results}

3.1 Seasonal variations of the thermodynamic properties of the copper binding ligands in the MELIMEX containers

The copper complexing capacities $\mathrm{X}_{\mathrm{Cu}}$ and the conditional complex formation constant $\mathrm{K}_{\mathrm{X}}$ as a function of time are compared in figure 6. Although the conditional formation constants for the loaded containers were significantly higher than those in the control in May and June 1977 and March 1978, the overall 

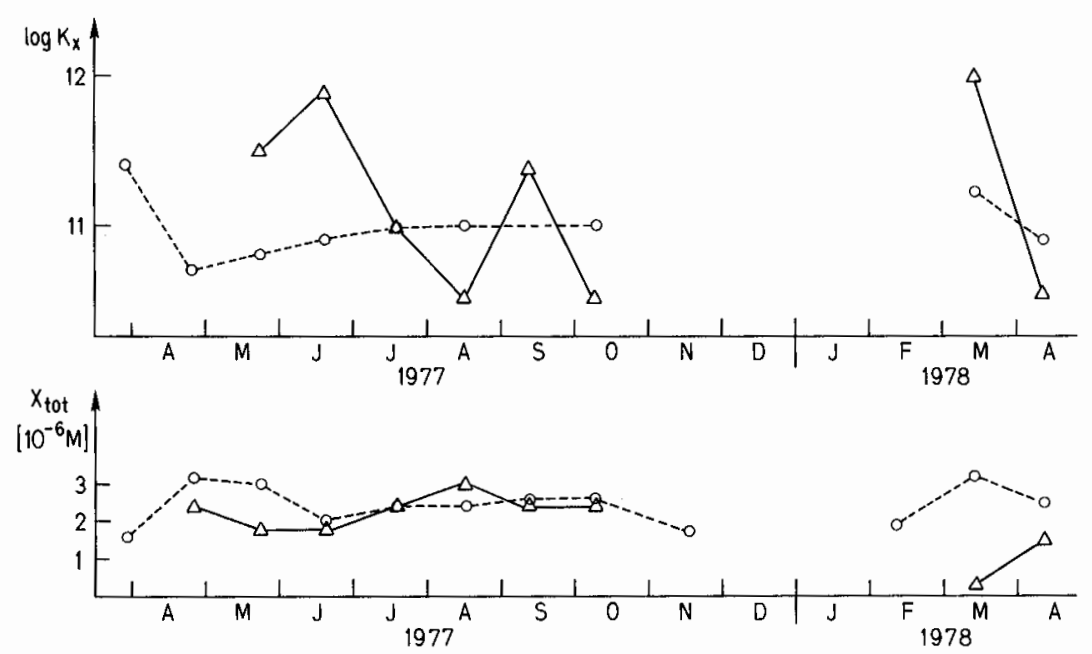

Figure 6. Seasonal variations of $\mathrm{K}_{\mathrm{X}}$ (conditional formation constant for $\mathrm{CuX}$ ) and $\mathrm{X}_{\text {tot }}$ (organic ligand concentration) in the MELIMEX corrals.

$\triangle-\triangle$ corral $\mathrm{L}, \mathrm{O}----\mathrm{O}$ corral $\mathrm{C}$.

Abb.6. Saisonale Veränderung der $\mathrm{K}_{\mathrm{X}}$-Werte (konditionelle Komplexbildungskonstante für $\mathrm{CuX}$ ) und $\mathrm{X}_{\text {tot }}$ (Konzentration der organischen Liganden) in den MELIMEX-Corrals.

differences are very small as can be seen from the arithmetic mean values for the whole observation period (table 3 ).

Table 3. Mean values of $\mathrm{X}_{10 \mathrm{t}}$ and $\mathrm{K}_{\mathrm{X}}$ for the period between March 1977 and April 1978.

Tabelle 3. Mittlere Werte von $\mathrm{X}_{\text {tot }}$ und $\mathrm{K}_{\mathrm{X}}$ für die Periode zwischen März 1977 und April 1978.

\begin{tabular}{lll}
\hline Corral & $\mathrm{X}_{\text {tot }}\left(10^{-6} \mathrm{M}\right)$ & $\log \mathrm{K}_{\mathrm{X}}(\mathrm{pH}=8.8)$ \\
\hline Control & $2.4 \pm 0.5$ & $11.0 \pm 0.2$ \\
& $(\mathrm{n}=13)$ & $(\mathrm{n}=9)$ \\
Loaded & $2.3 \pm 0.5$ & $11.1 \pm 0.5$ \\
$(\mathrm{n}=9)$ & $(\mathrm{n}=8)$ \\
\hline
\end{tabular}

$\mathrm{n}=$ number of determinations.

There are two main factors that could influence the complex binding properties of the organic ligands, namely the proton concentration and the competition of other cations present such as $\mathrm{Ca}^{2+}, \mathrm{Fe}^{2+}, \mathrm{Zn}^{2+}, \mathrm{Cd}^{2+}$ and $\mathrm{Pb}^{2+}$. The $\mathrm{pH}$ variation in the epilimnion of both loaded and unloaded corrals was found to range from 7.6 to 9.2 (fig. 7).

The $\mathrm{pH}$ dependence of the stability constant for a lake water sample is given in figure 8 . The values of $\mathrm{K}_{\mathrm{X}}$ for a lake water sample were determined at different pH's with the method described in section 2.6. It can be concluded that between pH 8 and $9 \mathrm{~K}_{\mathrm{X}}$ changes approximately one order of magnitude.

The influence of other cations was evaluated in three separate amperometric titration experiments. In one the concentrations of $\mathrm{Zn}^{2+}, \mathrm{Cd}^{2+}$ and $\mathrm{Pb}^{2+}$ in the concentrated lake water sample were adjusted to equal those in the dissolved 
fraction of the loaded corral [2]. $\mathrm{Hg}$ was neglected because of the low $\mathrm{DHg}$ value [2]. Due to the low solubility of $\mathrm{CaCO}_{3}$ the influence of $\mathrm{Ca}^{2+}$ could not be tested in $0.1 \mathrm{M} \mathrm{NaHCO}$. Instead an amperometric titration with copper was performed in $0.1 \mathrm{M} \mathrm{KNO}_{3}$ with $10^{-2} \mathrm{M}$ malonic acid at a $\mathrm{pH}=7.3 \pm 0.1$. Beyond
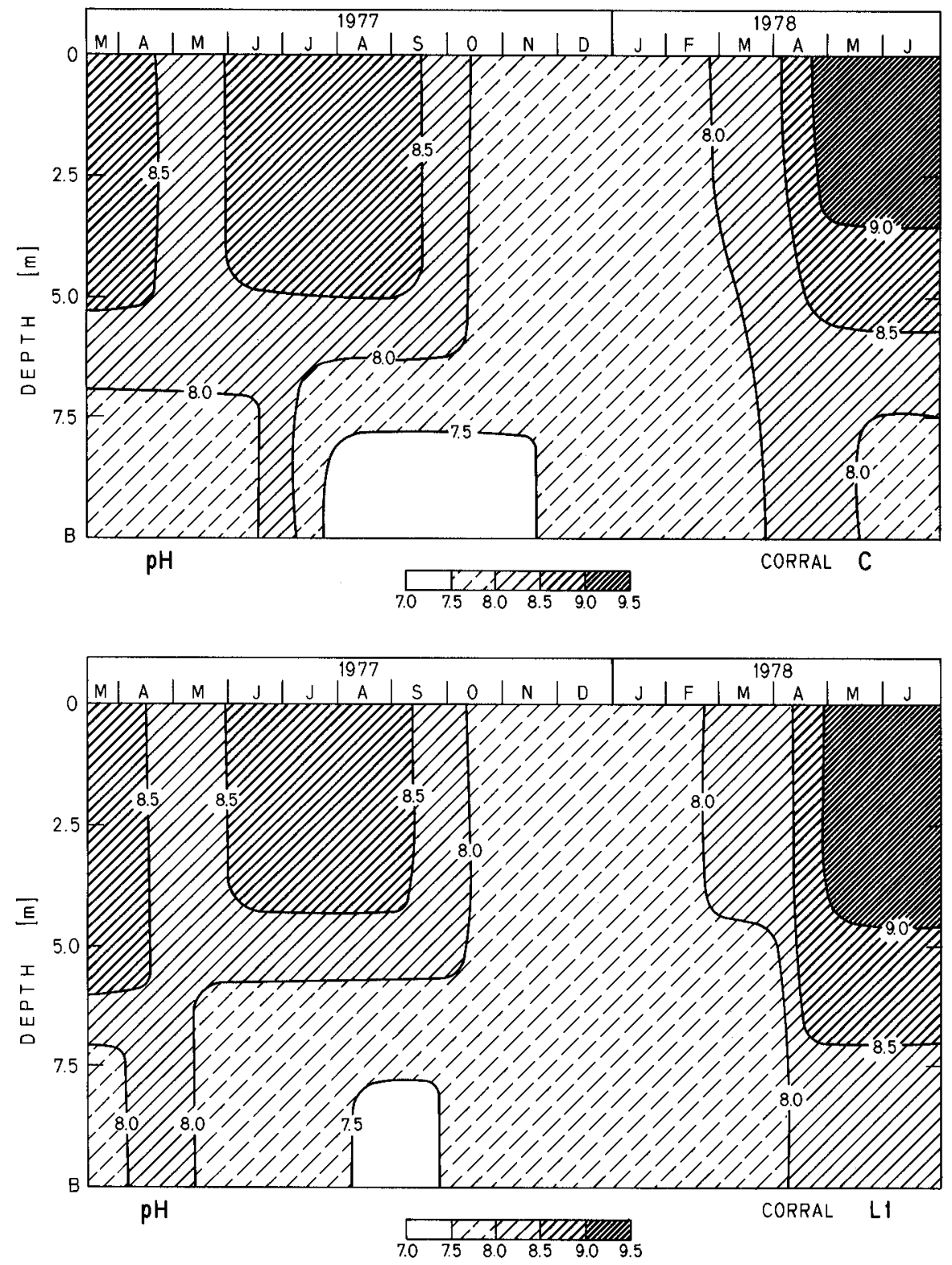

Figure 7. Isopleths of $\mathrm{pH}$ of loaded corral $\mathrm{L} 1$ and control corral $\mathrm{C}$. Abb. 7. pH-Isoplethen des belasteten Corrals L 1 und des Kontroll-Corrals. 


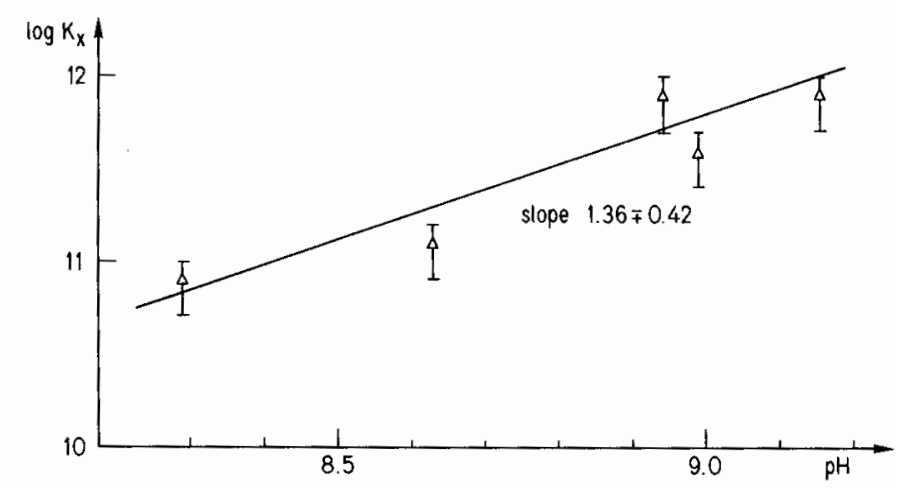

Figure 8. $\mathrm{pH}$ dependence of the conditional complex formation constant $\mathrm{K}_{\mathrm{X}}$. Sample: Corral C, November 1978.

Abb. 8. pH-Abhăngigkeit der konditionellen Komplexbildungskonstanten $\mathrm{K}_{\mathrm{X}}$. Probe: Corral C, November 1978.

the equivalence point the electroactive species would be copper malonate complexes. The third experiment was designed to test the influence of $\mathrm{Fe}^{3+}$. Here $\mathrm{Fe}^{3+}$ was added to $0.1 \mathrm{M} \mathrm{NaHCO} 3(\mathrm{pH}=8.8)$ in a concentration equal to the mean concentration of dissolved species. The results are summarized in table 4 and indicate that none of the cations evaluated can reduce significantly the complexing capacity for copper.

Table 4. Influence of other cations on copper complexing capacity $\mathrm{X}_{\text {tot }}$.

Tabelle 4. Einfluss anderer Kationen auf die Kupferkomplexbildungskapazität $X_{\text {tot }}$.

\begin{tabular}{|c|c|c|c|}
\hline Sample & Medium & Cations & $\mathrm{X}_{\mathrm{tot}}(\mathrm{CF}=1)$ \\
\hline $\begin{array}{l}\text { C } \\
\text { (January 1978) }\end{array}$ & $\begin{array}{l}0.1 \mathrm{M} \mathrm{NaHCO} \\
\mathrm{pH}=8.8\end{array}$ & $\begin{array}{l}\left(\mathrm{Zn}^{2+}\right): 1.2 \times 10^{-4} \mathrm{M} \\
\left(\mathrm{Cd}^{2+}\right): 7.1 \times 10^{-6} \mathrm{M} \\
\left(\mathrm{Pb}^{2+}\right): 1.6 \times 10^{-6} \mathrm{M} \\
(\mathrm{CF}=40)\end{array}$ & $2.5 \pm 0.210^{-6} \mathrm{M}$ \\
\hline $\mathrm{CF}=40$ & & - & $2.6 \pm 0.210^{-6} \mathrm{M}$ \\
\hline $\begin{array}{l}\text { C } \\
\text { (February 1978) }\end{array}$ & $\begin{array}{l}0.1 \mathrm{M} \mathrm{KNO}_{3} \\
0.01 \mathrm{M} \text { malonic acid }\end{array}$ & $\begin{array}{l}\left(\mathrm{Ca}^{2+}\right): 3.0 \times 10^{-2} \mathrm{M} \\
(\mathrm{CF}=20)\end{array}$ & $1.7 \pm 0.110^{-6} \mathrm{M}$ \\
\hline $\mathrm{CF}=20$ & $\mathrm{pH}=7.3$ & - & $1.8 \pm 0.110^{-6} \mathrm{M}$ \\
\hline $\begin{array}{l}\text { C } \\
\text { (November 1978) }\end{array}$ & $0.1 \mathrm{M} \mathrm{NaHCO}_{3}$ & $\begin{array}{l}\left(\mathrm{Fe}^{3+}\right): 1.9 \times 10^{-6} \mathrm{M} \\
(\mathrm{CF}=40)\end{array}$ & $1.0 \pm 0.110^{-6} \mathrm{M}$ \\
\hline $\mathrm{CF}=40$ & $\mathrm{pH}=8.8$ & - & $1.1 \pm 0.110^{-6} \mathrm{M}$ \\
\hline
\end{tabular}

$\mathrm{C}=$ control corral.

3.2 Copper complexing capacity of different lake waters as a function of DOC concentration

The relatively small seasonal variations of the concentration of the dissolved organic substances in the epilimnic phase of the containers (fig. 9) do not allow the cor- 
relation of the observed DOC contents with measured values of X. However in figure 10 the copper complexing capacity of a number of lake waters having different DOC contents is shown. From this figure a mean copper binding ligand concentration of $5.5 \times 10^{-7}$ mole/ $\mathrm{mg} \mathrm{DOC}$ may be obtained.
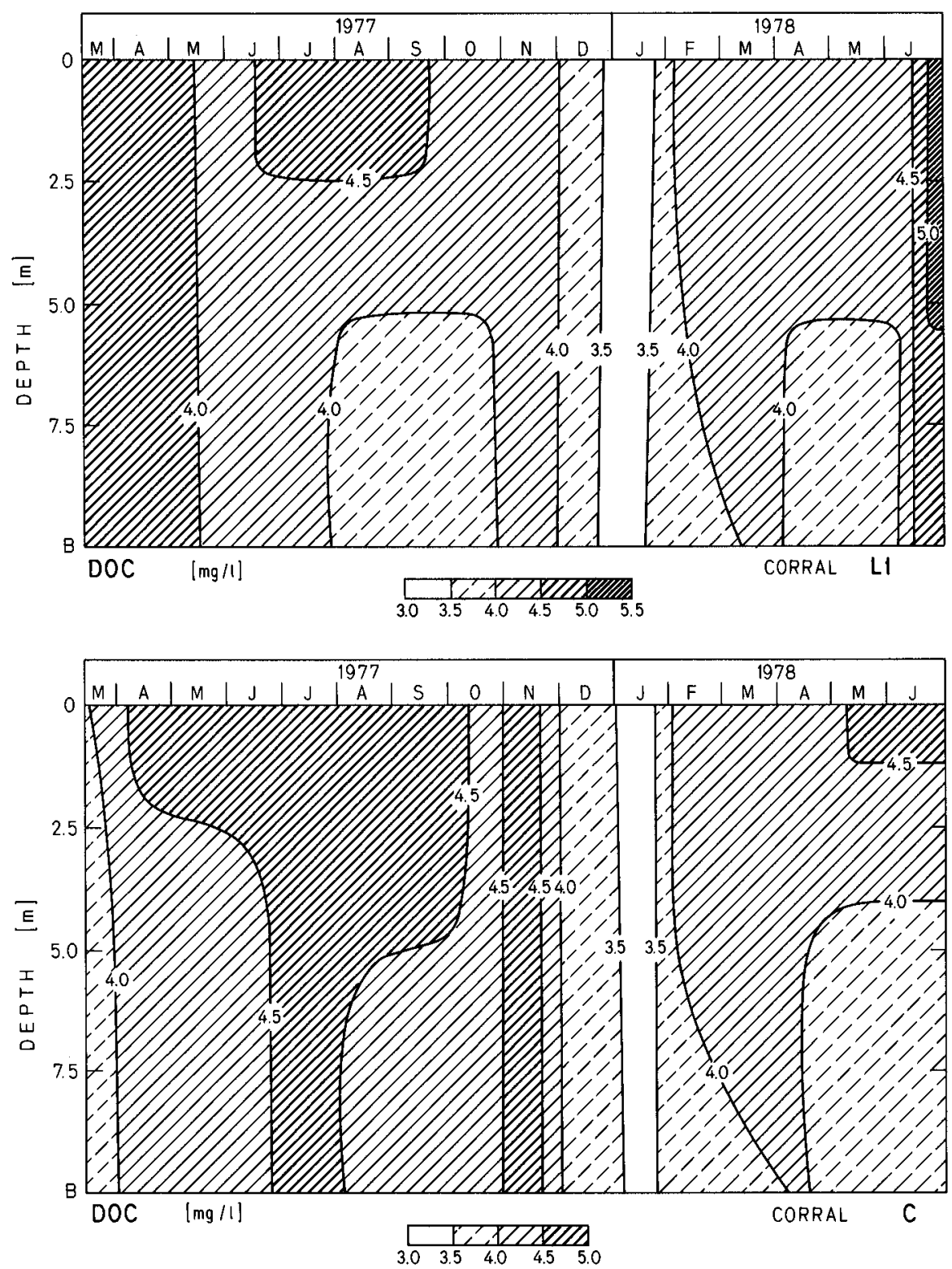

Figure 9. Isopleths of dissolved organic carbon (DOC) of corrals Ll and C.

Abb.9. Isoplethen des gelösten organischen Kohlenstoffs (DOC) der Corrals Ll und C. 


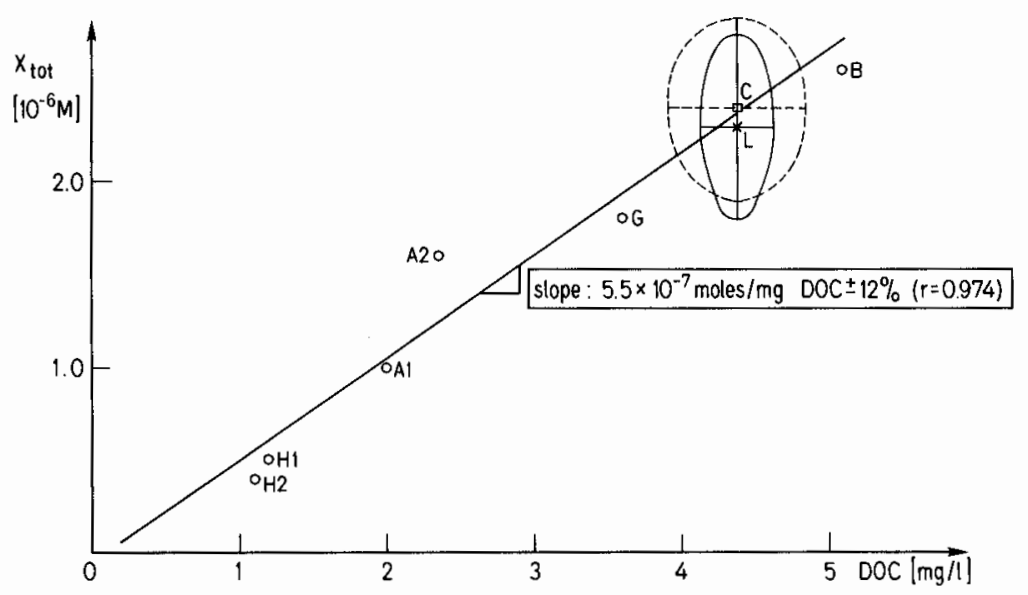

Figure 10. Copper complexing capacity $\mathrm{X}_{\text {tot }}$ as a function of DOC concentration.

A: Lake Alpnach (1: $30.6 .77,2: 14.6 .78)$.

B: Lake Baldegg (21.8.78).

C: MELIMEX corral C (mean value).

G: Greifensee (28.3.78).

H: Horwer Bucht (1: 13.2.78, 2: 28.3.78).

L: MELIMEX corral L (mean value).

Abb. 10. Komplexierungskapaziät $X_{\text {tot }}$ für Kupfer als Funktion der DOC-Konzentration.

\subsection{Copper binding properties of different molecular size fractions}

\subsection{Seasonal variations of copper distribution in Sephadex G-150 filtration}

During the observation period (from March 1977 to November 1977) the fractioning of lake water concentrates from the limno-corrals gave almost identical distribution patterns on Sephadex G-150. Fractions with high UV absorption ( $254 \mathrm{~nm}$ ) contained also high $\mathrm{Cu}$ concentrations. Typical elution diagrams are shown in figure 11 . No significant differences were detected between samples $\mathrm{L}$ and $\mathrm{C}$. Thus the additional copper (increased on average by a factor 5 ) is distributed similarly in respect to molecular sizes. It can also be concluded that the bulk of copper species must have molecular sizes smaller $10^{4}$ daltons.

\subsection{Copper binding properties of fractions obtained by membrane filtration}

A concentrated sample from the control corral (August 1978) was separated by ultrafiltration U (AMICON) and molecular filtration M (Millipore). The different properties measured are summarized in table 5 .

Although both methods give a nominal separation limit of $10^{3}$ daltons the fractioning effect is different. The molecular filtration indicates that practically all copper binding ligands must have a molecular weight smaller than $10^{4}$ daltons which is in agreement with the gel filtration observation. The ultrafiltration experiments 


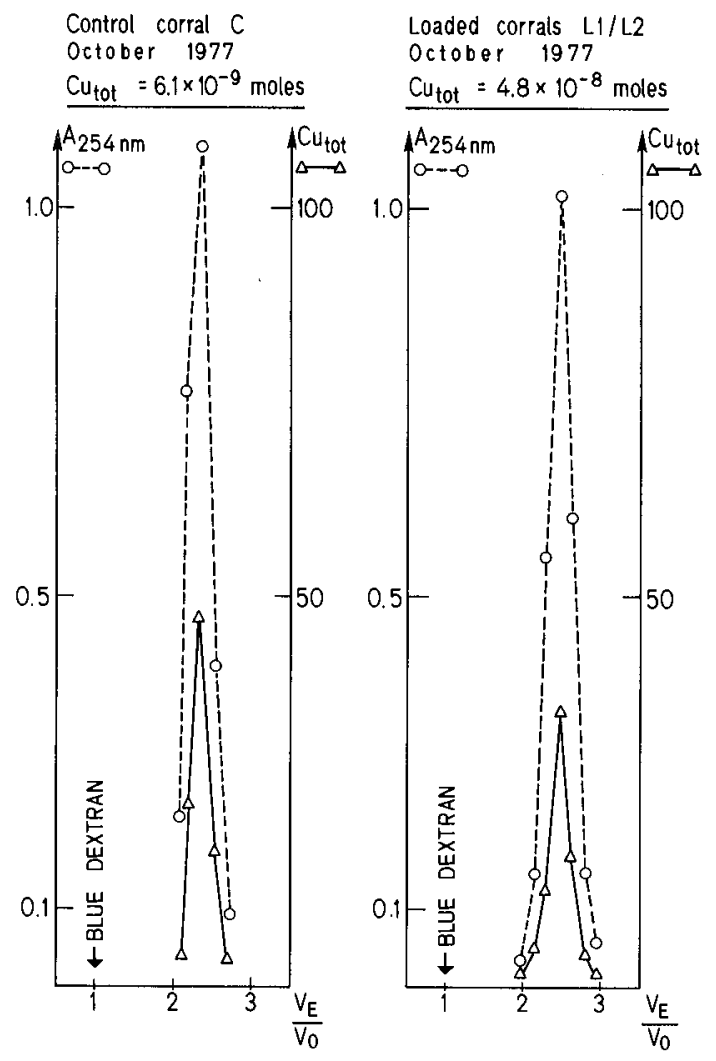

Figure 11. Copper distribution in Sephadex G-150 fractioning of concentrated lake water. $A_{254}$ nm: Absorbance of dissolved organic substances in aqueous solution at $254 \mathrm{~nm}\left(0.01 \mathrm{M} \mathrm{NaHCO}_{3}\right.$, $\mathrm{pH}=8.1$ ). $\mathrm{V}_{\mathrm{E}}$ : Elution volume.

$\mathrm{V}_{0}$ : Volume of the mobile phase of the column.

Abb. 11. Kupferverteilung in der Fraktionierung von Seewasserkonzentrat mit Sephadex G-150.

A $254 \mathrm{~nm}$ : Absorption der gelösten organischen Substanzen in wässeriger Lösung bei $254 \mathrm{~nm}$ $\left(0,01 \mathrm{M} \mathrm{NaHCO}_{3}, \mathrm{pH}=8,1\right)$.

$\mathrm{V}_{\mathrm{E}}$ : Elutionsvolumen.

$\mathrm{V}_{0}$ : Volumen der mobilen Phase der Säule.

indicate however that there is a significant fraction of $\mathrm{X}$ having molecular sizes within $10^{4}$ and $10^{3}$ daltons. In both separations the DOC distribution corresponds well with the copper distribution. The complex formation constants of the filtrates are not significantly different from the educt sample. However the complexing capacity per mg DOC of the ultrafiltrate is almost twice as high as that of the retentate.

\subsection{Copper complexing capacities of Sephadex G-25 fractions}

The same educt as described above was used. The elution diagram is shown in 
Table 5. Copper binding properties of fractions obtained by membrane filtration.

Tabelle 5. Kupferbindende Eigenschaften der Membranfiltration-Fraktionen.

\begin{tabular}{lllllll}
\hline Sample & $\begin{array}{l}\mathrm{DOC} \\
(\mathrm{mg} / \mathrm{l}) \mathrm{FC}=1\end{array}$ & $\begin{array}{l}\text { \% of } \\
\mathrm{DOC}_{\text {tot }}\end{array}$ & $\begin{array}{l}\mathrm{X}_{\mathrm{tot}} \\
\left(0^{-7} \mathrm{~mole} / \mathrm{mg} \mathrm{DOC}\right)\end{array}$ & $\begin{array}{l}\% \text { of } \\
\mathrm{X}_{\text {tot }}\end{array}$ & $\begin{array}{l}\log \mathrm{K}_{\mathrm{X}} \\
(\mathrm{pH}=8.8)\end{array}$ & $\begin{array}{l}\% \text { of } \\
\mathrm{Cu}_{\text {tot }}\end{array}$ \\
\hline $\begin{array}{l}\text { Lake water } \\
(<0.45 \mu \mathrm{m})\end{array}$ & 5.1 & 100 & $5.2 \pm 0.5$ & 100 & 10.9 & 100 \\
M-retenate & 0.5 & 10 & n.d. & - & n.d. & 10 \\
M-filtrate & 4.5 & 88 & $6.3 \pm 0.6$ & $107 \pm 10$ & 10.8 & 90 \\
U-retenate & 3.6 & 71 & $4.7 \pm 0.3$ & $64 \pm 6$ & n.d. & 69 \\
U-filtrate & 1.7 & 33 & $9.0 \pm 0.9$ & $58 \pm 10$ & 10.8 & 31 \\
\hline
\end{tabular}

n.d. $=$ not determined $/$ n.d. $=$ nicht bestimmt .

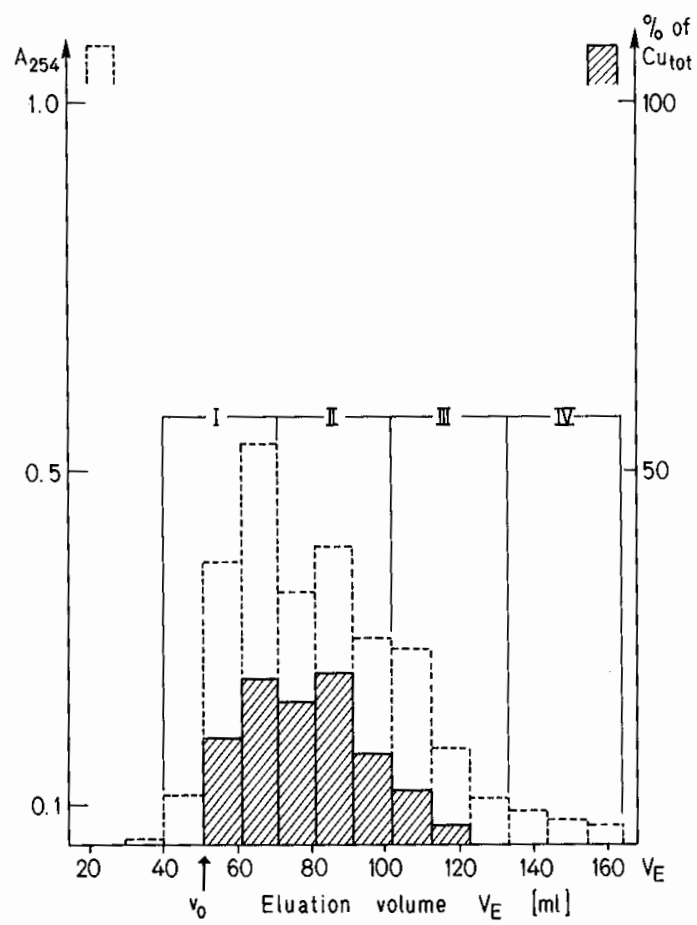

Figure 12. Copper distribution in Sephadex G-25 fractioning of concentrated lake water.

$A_{254 \mathrm{~nm}}$ : Absorption of dissolved organic substances in aqueous solution at $254 \mathrm{~nm}\left(0.01 \mathrm{M} \mathrm{NaHCO}_{3}\right.$, $\mathrm{pH}=8.1$.

$V_{E}$ : Elution volume.

$\mathrm{V}_{0}$ : Volume of the mobile phase of the column.

Abb. 12. Kupferverteilung in der Fraktionierung von Seewasserkonzentrat mit Sephadex G-25.

$\mathrm{A}_{254 \mathrm{~nm}}$ : A bsorption der geiösten organischen Substanzen in wässeriger Lösung bei $254 \mathrm{~nm}(0,01 \mathrm{M}$

$\mathrm{NaHCO}_{3}, \mathrm{pH}=8,1$ ).

$\mathrm{V}_{\mathrm{E}}$ : Elutionsvolumen.

$\mathrm{V}_{0}$ : Volumen der mobilen Phase der Säule. 
figure 12. Also shown on this diagram are the four subfractions that were chosen for further experiments the results of which are summarized in table 6 .

The elution diagram verifies the observations made above, namely that the dominant part of copper binding ligands have molecular sizes around $10^{3}$ daltons. Fractions I and II correspond approximately to the ultrafiltration retentate and fractions III and IV to the ultrafiltrate. Again it can be stated that high molecular sizes (fraction I) have a much lower complexing capacity per mg DOC than the small ones (fraction IV).

Table 6. Copper complexing capacities of Sephadex G-25 fractions.

Tabelle 6. Kupfer-Komplexbildungskapazität der Sephadex-G-25-Fraktionen.

\begin{tabular}{llllcr}
\hline Sample & $\begin{array}{l}\text { DOC } \\
(\mathrm{mg} / 1) \\
\mathrm{CF}=1\end{array}$ & $\begin{array}{l}\text { \% of } \\
\mathrm{DOC}_{\text {tot }}\end{array}$ & $\begin{array}{l}\mathrm{X}_{\text {tot }}^{\prime} \\
\left(10^{-7} \text { mole/mg DOC }\right)\end{array}$ & $\begin{array}{l}\% \text { of } \\
\mathrm{X}_{\text {tot }}\end{array}$ & $\begin{array}{l}\% \text { of } \\
\mathrm{Cu}_{\text {tot }}\end{array}$ \\
\hline $\begin{array}{l}\text { Lake water } \\
(<0.45 \mu \mathrm{m})\end{array}$ & 5.1 & 100 & $5.2 \pm 0.5$ & 100 & 100 \\
I $^{*}$ & & & & & \\
II & 1.6 & 31 & $2.7 \pm 0.3$ & 16 & 36 \\
III & 1.7 & 33 & $5.9 \pm 0.3$ & 38 & 54 \\
IV & 0.9 & 18 & $5.8 \pm 0.3$ & 20 & 9 \\
I-IV & 0.2 & 4 & $17.5 \pm 2.6$ & 13 & 1 \\
\hline
\end{tabular}

* Compare with figure 12/Vergleiche mit Abb. 12.

\section{Discussion}

\subsection{Aspects of the chemical nature of copper binding ligands}

The combination of thermodynamic and physicochemical properties presented in section 3 permit the following characterization:

1. The conditional formation constant $\mathrm{K}_{\mathrm{X}}$ of the ligand $\mathrm{X}$ obtained from lake water is at least two orders of magnitude greater than the ones of well described bidentate organic ligands, such as 5- and 6-rings with oxygen atoms from carboxylic acids and phenols, and nitrogen atoms from amino - and imino - groups. It follows that such a simple 1:1 binding size in a larger molecule cannot be responsible for the observed phenomenon unless the total charge of the molecule increases the stability of the individual chelate [14].

2. The results of the molecular size fractioning indicate that the bulk of the copper binding ligands must have molecular sizes between $1-3 \times 10^{3}$ daltons. It follows that a polyelectrolytic influence can hardly be responsible for the observed increase in stability of an individual binding size. However a chain structure of this size would permit the folding of the molecule leading eventually to tridentate or tetradentate arrangements having higher stabilities.

3. Additional copper is distributed analogously among the molecular size fractions (fig. 11) and different size fractions have similar conditional stability constants (table 5). This indicates that the binding sites or the ability to bind copper are distributed over the whole size range of the main fraction. 
4. Other cations in excess relative to copper, namely calcium(II) and iron(III) (table 4) do not reduce the copper binding properties of ligands in question. This indicates a type of ligand which must be more specific for copper than the functional groups in well-described synthetic reference ligands such as aminocarboxylic acids (e.g. EDTA, NTA) or model ligands for humic and fulvic acids (e.g. salicylic acids, phtalic acids). This observation is in agreement with the phenomenon described by Greter [15]. More specific ligands for copper among natural molecules can be found in peptide chains $[16,17]$. The $\mathrm{N}$-terminal end can form a tridentate ligand for copper in the $\mathrm{pH}$ region of lake water $(\mathrm{pH}=7.5-9)$.

5. Smaller molecular sizes have a higher number of copper binding sites per mg DOC (tables 5,6 ). The following structural properties could be responsable for such a phenomenon:

a) A chain polymer, e.g. a peptide, has only one preferential site, namely on one end of the molecule. The shorter the chain, the higher the number of binding sites per $\mathrm{mg}$ DOC.

b) A molecule is folded to form the most stable copper complex, e.g. a $\mathrm{CuN}_{4}$ or $\mathrm{CuN}_{2} \mathrm{O}_{2}$ chromophore. In molecules having sizes between 1 and $3 \times 10^{3}$ daltons a second site of the same quality would be very improbable or stereochemically impossible.

6. Concentrated samples from different lake waters do not differ significantly in their complexing capacity per mg DOC (fig. 10). The production of dissolved organic molecules in a lake is primarily due to the heterotrophic activity [18] starting from substances of the primary producers. If lakes of different trophic states and different catchment areas have a similar set of enzymes for the metabolism of organic substances one could expect very similar products in the bulk of the dissolved organic molecules. From this it is understandable why the loaded corrals and the control (table 3 ) do not give significant difference in their copper complexing capacity. The mean DOC content is in the same order of magnitude (fig. 9). However the conditional formation constants of the loaded corral show a more pronounced variation in function of time (fig. 6), indicating a variation in ligand chemistry. The only information about chemical differences in organic speciation is that the composition of the free amino acids in the loaded corrals differs from that in the control [19].

The starting material for the chemical characterization of copper is defined operationally (fig. 2). Therefore it is difficult to compare the observed properties with results from other authors employing different methods. Mantoura et al. [20] were among the few who determined stability constants of copper at $\mathrm{pH}=8.0$. The organic ligands from lake water were separated on an Amberlite XAD-2 resin. The values for $\log \mathrm{K}_{X}$ lay between 8.4 and 9.8. If one extrapolates these values to a $\mathrm{pH}=8.8$ according to the dependence described in figure 8 , one finds a $\log \mathrm{K}_{\mathrm{X}}$ range between 9.4 and 10.8. This range overlaps with that found for the total dissolved organic substances discussed in this work (table 3). For ponds and river waters Buffle et al. [10] found mean molecular weights of copper binding ligands around 1,700 daltons. The same author [21] supports our observation that the bulk of dissolved organic matter from fresh surface waters is within the molecular size range of $10^{4}$ to $10^{3}$ daltons. 
In conclusion dissolved copper in lake water and in the samples from the limnocorrals is complexed primarily by organic ligands which have molecular sizes within $10^{4}$ to $10^{3}$ daltons. The mean concentration of copper binding ligands is approximately $5 \times 10^{-7} \mathrm{~mole} / \mathrm{mg}$ DOC. The conditional stability constants indicate chelate complexes which are relatively specific for copper under natural conditions and are most likely formed from polydentate ligands.

\subsection{The influence of chemical speciation on biological availability of copper}

It is obvious from the results presented in table 3 that the increased metal load in L1 and L2 did not lead to an increase of copper binding ligands. The biosphere reacted upon the metal stress by a shift in the phytoplankton community [3]. The resulting populations had significantly lower metal sorption capacity $[2,22]$ defined as the ratio of metal concentration in the biomass to the metal concentration in the dissolved aquatic phase. In the case of copper a decrease of sorption capacity could also be due to the increase of the stability of copper complexes which are biologically not available. Such increases were observed to occur on occasion (fig. 6). According to the observed $\mathrm{pH}$-dependency (fig. 8) an increase in $\mathrm{pH}$ does also increase the stability of the complexes.

In order to evaluate the possible influence of copper speciation on the uptake of this element by the biomass an equilibrium model for the copper speciation was employed which was introduced already elsewhere [23]. The inorganic species considered are given in figure 1 and the thermodynamic values of the undefined organic ligands are presented in figure 6. In all corrals the dominating species are the organic complexes which vary between 95 and $99 \%$ of total dissolved copper. Furthermore it is assumed that the concentration of metal in the biomass is directly proportional to the concentration of the available inorganic species, namely $\mathrm{Cu}^{2+}$ [4-7]. The calculated concentration of $\mathrm{Cu}^{2+}$ as a function of time is compared with the copper concentration found in the organic fraction of the sedimenting material [2]. The results are summarized in figure 13 and permit the following interpretations:

1. In the control corral the copper in the biomass over the study period corresponds with the calculated available copper species (fig. 13). The decrease in the months of July and August 1977 and the peaks in the winter months can be explained with the variations of $\mathrm{pH}$ increasing or decreasing the stability of the biologically non-available organic complexes (fig. 8). In the loaded corrals the same tendency is recognizable but the speciation model does not correspond as well with the observed copper contents in the biomass during the first half of the observation period.

2. A linear regression analysis for copper content in biomass as a function of $\mathrm{Cu}^{2+}$ indicates that at least one additional factor must influence the uptake of copper. The slope $(0.88$ for $\mathrm{C}, 0.69$ for $\mathrm{L})$ is a measure for the sorption capacity of the biomass. The lower value of the loaded corral supports the findings [22] that the sorption capacity of the plankton selected because of a metal stress is generally smaller. 
In conclusion one can postulate that the organic ligands and the proton concentration are decisive factors for the biological availability of copper. However the sorption capacity of the biomass depends also on the variety of plankton species.

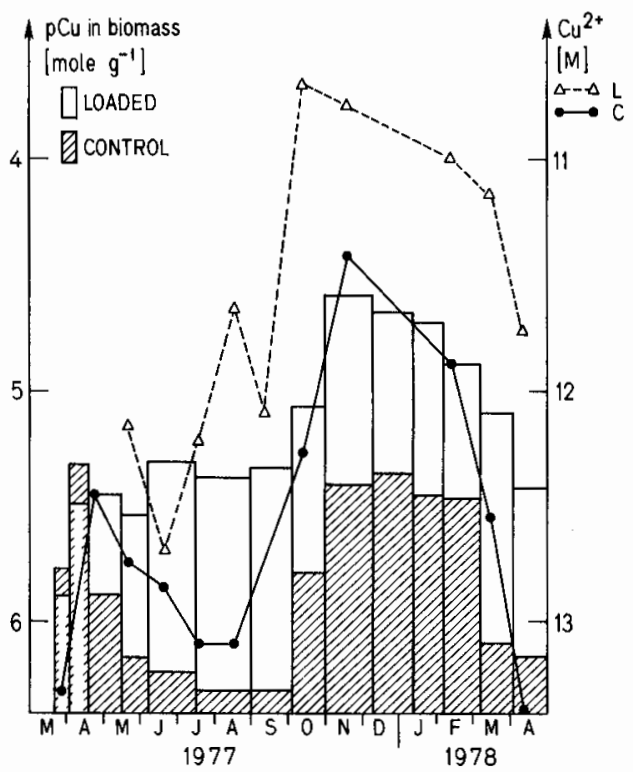

Figure 13. Comparison of the seasonal variation of the copper content in biomass with the corresponding variation of calculated $\mathrm{Cu}^{2+}$ concentration.

MELIMEX corrals loaded (L1, L2) and control (C).

Abb. 13. Vergleich der zeitlichen Variation des Kupfergehaltes in der Biomasse mit der entsprechenden Veränderung der berechneten $\mathrm{Cu}^{2+}$-Konzentration.

\section{Summary}

In the limno-corrals of the MELIMEX project the chemical speciation of dissolved copper $(<0.45 \mu \mathrm{m})$ was investigated. In order to characterize the thermodynamic properties of copper complexing ligands and their molecular size distribution a concentration procedure was employed (fig. 2). The equivalent concentration of copper binding ligands having conditional formation constants $(\mathrm{pH}=8.8)$ of at least $10^{10}$ were determined by amperometric titrations (fig. 3, 4). The complex formation constants were determined by applying the techniques of copper distribution between an ionic exchanger and an aquatic phase in a batch procedure [fig. 5 , eq. (11)]. The molecular size distribution was studied with gel filtration (fig.11, 12) and membrane filtration (table 5).

Dissolved copper in lake water and in the samples from the limno-corrals is complexed primarily $(\geq 95 \%)$ by organic ligands which have molecular sizes within $10^{4}$ and $10^{3}$ daltons. Their mean concentration is approximately $5 \times 10^{-7} \mathrm{~mole} / \mathrm{mg}$ 
DOC. The conditional stability constants indicate chelate complexes which are relatively specific for copper under natural conditions.

The increased metal load in the corrals L1 and L2 did not produce an increase of copper binding ligands (table 3 ). An equilibrium model for the copper speciation was employed to calculate the concentration of the biologically available $\mathrm{Cu}^{2+}$ ion. The seasonal variation of this ion-concentration was compared with the corresponding variation of the copper content in the biomass (fig. 13). It can be postulated that the organic ligands and $\mathrm{pH}$ are the most important factors in deciding the biological availability of copper. However the sorption capacity of the biomass depends also on the variety of plankton species.

\section{ZUSAMMENFASSUNG}

In drei Limno-Corrals des MELIMEX-Projektes wurde die chemische Speziierung des gelösten Kupfers $(<0,45 \mu \mathrm{m})$ untersucht. Zur Charakterisierung der thermodynamischen Eigenschaften kupferbindender Liganden und ihrer Molekulargewichtsverteilung wurde ein Konzentrierungsverfahren angewandt (Abb.2). Die Äquivalentkonzentration kupferbindender Liganden, die eine konditionelle Komplexbildungskonstante von mindestens $10^{10}(\mathrm{pH}=8,8)$ besitzen, wurden mit einer amperometrischen Titration bestimmt (Abb.3, 4). Zur Bestimmung der Komplexbildungskonstanten wurde die Methode der Kupferverteilung zwischen einem Ionenaustauscher und der wässerigen Phase im "Batch»-Verfahren angewandt [Abb. 5, Gl. (11)]. Die Molekulargewichtsverteilung wurde mit Hilfe der Gelfiltration (Abb.11, 12) und der Membranfiltration (Tab.5) untersucht.

Gelöstes Kupfer in Seewasser und in Proben aus den Limno-Corrals wird hauptsächlich ( $295 \%)$ mit organischen Liganden komplexiert, deren Molekulargewichte zwischen $10^{4}$ und $10^{3}$ Daltons liegen. Ihre mittlere Konzentration ist ungefähr $5 \times 10^{-7} \mathrm{Mol} / \mathrm{mg}$ DOC. Die konditionellen Stabilitätskonstanten der Komplexe weisen auf organische Liganden, die unter natürlichen Bedingungen relativ spezifisch für Kupfer sind.

Die erhöhte Metallbelastung in den Behältern L1 und L2 führte nicht zu einer Konzentrationserhöhung von kupferbindenden Liganden (Tab.3). Für die Berechnung der Konzentration biologisch verfügbarer $\mathrm{Cu}^{2+}$-Ionen wurde ein Gleichgewichtsmodell verwendet. Die saisonale Änderung der $\mathrm{Cu}^{2+-K o n z e n t r a t i o n}$ wurde mit der entsprechenden Variation des Kupfergehalts in der Biomasse verglichen (Abb.13). Es wird postuliert, dass organische Liganden und der $\mathrm{pH}$ die wichtigsten Faktoren für die Regulierung der biologischen Verfügbarkeit von Kupfer sind. Die Kupferaufnahmekapazität der Biomasse hăngt jedoch auch von der Zusammensetzung des Planktons ab.

\section{RESUME}

Dans trois limno-corrals du projet MELIMEX les especes chimiques de cuivre dissout $(<0,45 \mu \mathrm{m})$ ont été étudiées. Afin de caractériser les propriétés thermodynamiques des ligands complexant le cuivre et leur distribution des poids moléculaires un processus de concentration a été employé (fig. 2).

La concentration équivalente des ligands liant le cuivre a été déterminée par titration ampérométrique (fig. 3, 4). Les constantes de formation qui doivent avoir une valeur minimale de $10^{10}$ à un $\mathrm{pH}=8,8$, ont été déterminées en employant une technique de répartition de cuivre entre un échangeur d'ions et une phase aqueuse [fig.5, éq. (11)]. La distribution des poids moléculaires a été étudiée avec des filtrations de gel (fig. 11, 12) et des filtrations de membrane (table 5).

Le cuivre dissout dans l'eau lacustre et dans les échantillons des limno-corrals est complexé en première ligne $(\geq 95 \%)$ par des ligands organiques qui possèdent des poids moléculaires entre $10^{4}$ et $10^{3}$ daltons. La concentration moyenne est environ $5 \times 10^{-7} \mathrm{~mole} / \mathrm{mg}$ DOC. Les constantes conditionnelles de formation indiquent des complexes chélates qui sont relativement spécifiques pour le cuivre aux conditions naturelles.

Une charge de métal supplémentaire dans les corrals $L 1$ et $\mathbf{L} 2$ n'a pas produit une augmentation des ligands liant le cuivre (tabl.3). Un modèle d'équilibre pour les espèces chimiques de cuivre a été 
employé pour calculer la concentration de $\mathrm{Cu}^{2+}$ qui est disponible biologiquement. La variation saisonnière de la concentration $\mathrm{du} \mathrm{Cu}^{2+}$ a été comparée avec la variation correspondante de la teneur de cuivre dans la biomasse (fig.13). On peut postuler que les ligands organiques et le pH sont les facteurs les plus importants pour la régulation de la disponibilité biologique de cuivre. Mais la capacité d'assimilation de la biomasse dépend aussi de la variété du plancton.

\section{ACKNOWLEDGMENTS}

The authors wish to thank Prof. K. Bernauer, Prof. B.T. Hart and Dr. J. Westall for their constructive comments. We thank $\mathrm{A}$. Widmer and $\mathrm{H}$. Bolliger for writing and illustrating the manuscript.

\section{REFERENCES}

1 Baccini, P.: Schweiz. Z. Hydrol. 38, 121-158 (1976).

2 Baccini, P., Ruchti, J., Wanner, O., and Grieder, E.: Schweiz. Z. Hydrol. 41, 202-227 (1979).

3 Gächter, R., and Máreš, A.: Schweiz. Z. Hydrol. 41, 228-246 (1979).

4 Sunda, W., and Guillard, R.R.L.: J. mar. Res. 34, 511-529 (1976).

5 Bundi, Th.: Ph.D. thesis, Swiss Federal Institute of Technology, in preparation.

6 Anderson, D.M., and Morel, F. M.N.: Limnol. Oceanogr. 23/2, 283-295 (1978).

7 Gächter, R., Davis, J.S., and Máres, A.: Envir. Sci. technol. 12/13, 1416-1421 (1978).

8 Stumm, W., and Morgan, J. J.: Aquatic Chemistry. Wiley Interscience, New York 1970.

9 Jackson, G.A., and Morgan, J.J.: Limnol. Oceanogr. 23/2, 268-282 (1978).

10 Buffle, J., Greter, F. L., and Haerdi, W.: Analyt. Chem. 49/2, 216-222 (1977).

11 Hanck, K.W., and Jillard, J.W.: Analyt. Chim. Acta 89/2, 329-338 (1977).

12 Allen, H.E., Matson, W.R., and Mancy, K.H.: J. Wat. Pollut. Control Fed. 42, 573 (1970).

13 Chau, Y.K., and Lum-Shue-Chan, K.: Water Res. 8, 383 (1974).

14 Tanford, C.: Physical chemistry of macromolecules. Wiley Interscience, New York 1967.

15 Greter, F.C.: Ph.D. thesis, University of Geneva, 1978.

16 Kaneda, A., and Martell, A.E.: J. Coord. Chem. 4, 137-151 (1975).

17 Margerum, D.W., and Dukes, G.R.: Metal ions in biological system, vol. 1, chap.5. Ed. H.Sigel. Marcel Dekker, New York 1974.

18 Steinberg, C.: Arch. Hydrobiol., suppl. 53/1, 48-158 (1977).

19 Leidner, H.A., unpublished results.

20 Mantoura, R.F.C., Dickson, A., and Riley, J.P.: Estuar. Cost. Mar. Sci. 6, 387-408 (1978).

21 Buffle, J., Deladoey, P., and Haerdi, W.: Analyt. Chim. Acta 101, 329-357 (1978).

22 Gächter, R., and Geiger, W.: Schweiz. Z. Hydrol. 41, 277-290 (1979).

23 Baccini, P., Hohl, H., and Bundi, Th.: Verh. int. Ver. theor. angew. Limnol. 20, 1971-1975 (1978).

24 Ernst, R., Allen, H.E., and Mancy, K.A.: Water Res. 9 , 1969 (1975).

25 Gächter, R.: Schweiz. Z. Hydrol. 41. 169-176 (1979).

26 Brezonik, P.L., Brauner, P.A., and Stumm, W.: Water Res. 10, 605-612 (1976).

Address of the authors: Dr. P. Baccini, Ursula Suter, Seenforschungslaboratorium EAWAG/ETH, CH-6047 Kastanienbaum, Switzerland. 